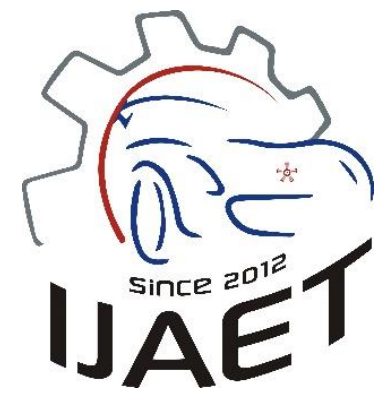

e-ISSN: 2146 - 9067

International Journal of Automotive

Engineering and Technologies

journal homepage:

https://dergipark.org.tr/en/pub/ijaet

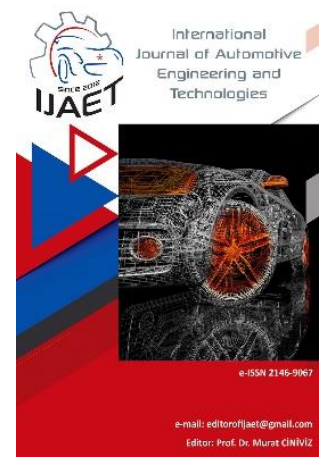

Original Research Article

\title{
A study on the estimation of fuel consumption and emitted emissions from vehicles in Turkey until 2050
}

\begin{tabular}{|c|c|}
\hline \multicolumn{2}{|c|}{ Ahmet Rasim Girişen ${ }^{*}$, Hakan Özcan ${ }^{2}$, Abdülvahap Çakmak ${ }^{3}$, Bilal Genez ${ }^{4}$} \\
\hline RTICLE INFO & ABSTRACT \\
\hline $\begin{array}{l}\text { Drcid Numbers } \\
1.0000-0002-1201-7614\end{array}$ & $\begin{array}{l}\text { In this study, the number of vehicles, fuel consumption, and emissions was estimated } \\
\text { in two scenarios by using the logistic model until } 2050 \text {. The fuel consumption } \\
\text { estimations were studied in three groups as diesel, LPG, and gasoline. Also, diesel }\end{array}$ \\
\hline . $0000-0002-7848-3650$ & r cars, light-duty, and heavy-duty \\
\hline 3. 0000-0003-1434-6697 & $\begin{array}{l}\text { vehicles. The annual mileage values of the vehicles and the average fuel co } \\
\text { per } 100 \mathrm{~km} \text { have been calculated by considering similar studies and statist }\end{array}$ \\
\hline 4. $0000-0003-1344-6338$ & estimates of the number of vehicles have been made considering that the $p$ \\
\hline Doi: $10.1824 /$ ijaet. 815450 & $\begin{array}{l}\text { of diesel vehicles will decrease in the next few ye } \\
\text { vehicles in specific regions and the increasing } d\end{array}$ \\
\hline $\begin{array}{l}\text { * Corresponding author } \\
\text { ahmetrasimgirisen@gmail.com }\end{array}$ & $\begin{array}{l}\text { vehicles. Emission estimates were made by considering the European Emission } \\
\text { Standart and future expectations of Euro norms. The total fuel consumption was }\end{array}$ \\
\hline eceived: Oct 23, 2020 & estimated as 10347 million liters (ML) gasoline, 50978 ML diesel, 12767 ML LPG, \\
\hline Accepted: Oct 08, 2021 & $\begin{array}{l}\text { and } 9390 \mathrm{ML} \text { gasoline, } 45171 \mathrm{ML} \text { diesel, and } 11568 \mathrm{ML} \text { LPG, respectively by the } \\
\text { normal and optimistic scenario for } 2050 \text {. The results also show that the total fuel }\end{array}$ \\
\hline Published: 09 Nov 2021 & consumption in 2050 will increase by 2.75 and 2.46 times, respectively, for the \\
\hline $\begin{array}{l}\text { Published by Editorial Board } \\
\text { Members of IJAET }\end{array}$ & $\begin{array}{l}\text { normal and optimistic scenario compared with fuel consumption in } 2018 \text {. When } \\
\text { emission estimates are examined, the increase in the number of electric/hybrid }\end{array}$ \\
\hline $\begin{array}{l}\text { (c) This article is distributed by } \\
\text { Turk Journal Park System under } \\
\text { the CC } 4.0 \text { terms and conditions. }\end{array}$ & $\begin{array}{l}\text { vehicles will reduce the emission amounts. If the two scenarios are compared for } \\
2050 \text {, it is seen that the amount of } \mathrm{CO}_{2} \text { in scenario B is } 11.39 \% \text { less than the amount } \\
\text { in scenario A. In this case, the presence of } 9.6 \% \text { electric/hybrid vehicles in the market } \\
\text { in the next } 30 \text { years brings about } 11 \% \text { less greenhouse gas emissions from vehicles. } \\
\text { Keywords: Emissions, Vehicle numbers, Fuel consumption, Predictions, Logistic model }\end{array}$ \\
\hline
\end{tabular}

\section{Introduction}

Global warming due to greenhouse gases has attracted the attention of researchers and governments in the last decades. Global warming caused by greenhouse gases, where fossil fuels also play a significant role in their formation, adversely affects climates, animal species, plant species, and people in many parts of the world. It can be listed the main health effects of air pollution on people as respiratory infection, skin and eye irritation, and cancer. Many precautions have been taken to reduce pollutants from vehicles. Emission norms, quality requirements for fuels, and taxes for the vehicle can be shown as examples. Although passenger vehicle taxes in Turkey are higher 
than almost all European countries [1], The number of motor vehicles per person has increased by $128 \%$ from 2003 to 2018 in Turkey, according to Turkey Statistical Institute data [2]. The increase in the number of vehicles also increased fossil fuel consumption across the country. From 2013 to 2018, total gasoline and diesel sales increased by $45.8 \%$ [3]. Hence, emissions from vehicles have also increased in this period. In our country, EURO 5 and EURO 6 standards have been introduced in new vehicles to reduce emission values. In this way, despite the increasing number of vehicles, the rising rate of the quantity of emissions has been slightly controlled. In the existing literature, many different methods have been used to estimate the vehicle number, fuel consumption, and the amount of emissions emitted from vehicles in the future. Gompertz function, logistic model, artificial bee colony algorithm, and part flock optimization can be given as examples for estimation methods. In this study, the vehicle number estimates were made using the logistic model. The logistics model has been widely used in medicine, economy, meteorology, agriculture, and transportation fields in recent years. Many studies have been conducted on the logistics model in the literature [4-7]. Similar studies existing in the literature were examined. In this context, $\mathrm{Wu}$ et al. [8] used the logistic model to simulate China's vehicle population's future trend and estimated the development of China's auto industry during 2020-2050. They used two different scenarios for estimating the future directions of the industry. In the first scenario, the results were obtained using local data. In the second scenario, the results were obtained using the data of the European countries. While the emission calculations were made, emission standards that the vehicles should comply with, and the percentage of these vehicles were used. The study results revealed that the number of vehicles would have increased by 15 times from 2008 through 2050, and fuel consumption in 2022 will happen two times that 2011. According to the estimated emission results, it was concluded that it would be appropriate to apply at least Standard VI between 2017-2021. Han et al. [10] evaluated the $\mathrm{CO}_{2}$ emissions from passenger cars on a global scale. International Organization of Motor Vehicle
Manufacturers (OICA) data, a comprehensive database, was used in their study. The forecast values cover emissions between 2000-2050. In that study, they made calculations for different countries by using future vehicle estimation, vehicle sales numbers, GNP (Gross National Product), and vehicle sales flexibility values. From the study, it was concluded that the $\mathrm{CO}_{2}$ emission, which was $2226 \mathrm{Mt}$ in 2000 , increased by $8.7 \%$ in 2013 and reached $2810 \mathrm{Mt}$. Besides, the maximum $\mathrm{CO}_{2}$ emission by 2050 was found to be 2923 Mt. Solmaz and Çelikten [11] estimated the number of vehicles, fuel consumption, and pollutant emissions in case of Turkey until the year 2030. The study was carried out using MATLAB and DELPHI programs. They used the data between 20012007 in their study. They ignored motorcycles and classified the vehicles as cars, light commercial vehicles, heavy trucks, minibuses, and buses.

Besides, they estimated the number of vehicles by fitting a fourth-degree curve to the statistical data. As a result of the study, they calculated the number of vehicles as 25.294 million, increasing $116 \%$ in 2030, compared to 2010. Examined the emission values, the total amount of $\mathrm{CO}, \mathrm{HC}$, $\mathrm{PM}, \quad \mathrm{NO}_{\mathrm{x}}, \quad \mathrm{SO}_{\mathrm{x}}$ emissions were 1.897888 megatons (Mt) in 2010, and this value was calculated to be $3.785336 \mathrm{Mt}$ in 2030 .

In the literature, many internal and external factors have been considered when estimating the number of vehicles. The logistics model to be used in this study is a model that defines the trends of the dependent variable over time. It can adequately reflect the market expansion of new products, and this logistic model has the following specific characters; slow growth of the dependent variable at the initial stage, then experiencing a rapid increase stage, finally entering a market saturation stage [8]. Therefore, the number of vehicles, fuel consumption, and pollutant emissions were estimated in two scenarios by using the logistic model until 2050 for the case of Turkey in the present study. According to the authors' knowledge, there is no up-to-date study in the literature about the estimation of fuel consumption and emitted emissions from vehicles in Turkey until 2050.

Therefore, it is aimed to conduct this present study to fill the gap that exists in the literature. 
Such estimations could make a significant contribution both in science and forming policies.

\section{Methods and Data}

The differential form of the Logistic model can be written as follows [8]:

$$
\frac{d K_{t}}{d t}=\alpha \cdot K_{t} \cdot\left(1-K_{t}\right)
$$

Where, $K_{t}=S_{t} / S_{m} . S_{t}$ is vehicle count at time t. $S_{\mathrm{m}}$ is the maximum vehicle count and represents the instant increase rate. While $\left(1-\mathrm{K}_{\mathrm{t}}\right)$ $>0$, the vehicle population increases; while $(1-$ $\left.\mathrm{K}_{\mathrm{t}}\right)<0$, it decreases; while $\left(1-\mathrm{K}_{\mathrm{t}}\right)=0$, it remains stable [8]. Solving Eq. (1) by separating variables, we can obtain that:

$K_{t}=\frac{1}{1+e^{-(\beta+\alpha t)}}$

Where $\beta$ is a constant. The growth curve of the logistic model is shown in Figure 1. There is feedback $\left(\mathrm{K}_{\mathrm{t}},\left(1-\mathrm{K}_{\mathrm{t}}\right), \alpha\right)$ that regulates the number of vehicles among the three variables according to the maximum $S_{\mathrm{m}}$ value.

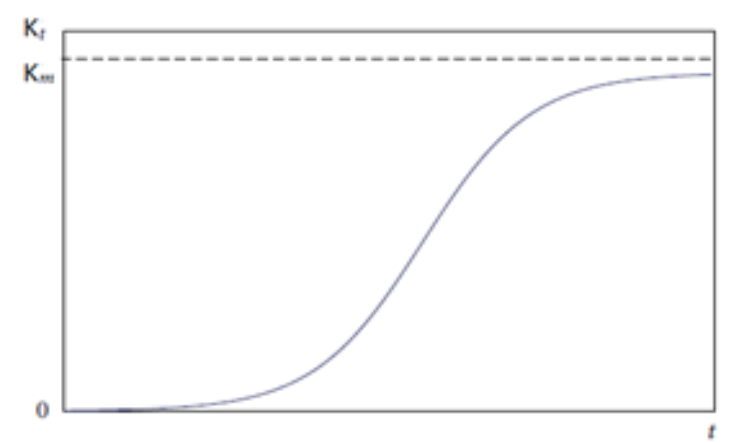

Figure 1. Logistic model curve adapted from Ref. [8]

By taking the logarithm of Eq. (2), we can obtain Eq. (3).

$\ln \frac{K_{t}}{\left(1-K_{t}\right)}=\alpha t+\beta$

Where $\ln \mathrm{K}_{\mathrm{t}}$ / (1- $\mathrm{K}_{\mathrm{t}}$ ) can be considered to show a linear relationship with $\mathrm{t}$. Model parameters $(\alpha$ and $\beta$ ) can be calculated according to Turkey's conditions by estimating the maximum count of vehicles in Turkey. The model parameters $(\alpha$ and $\beta$ ) given in equation (3) was determined as 0.0754 and 1.6977, respectively. Then equation (3) can be rewritten as follows:

$\ln \frac{K_{t}}{1-K_{t}}=0.0754 t-1.6977$

The statistical data and estimation of the number of vehicles were given in Table 2 for Turkey's vehicle population from 2007 to 2018 .

\section{Results and Discussions}

\subsection{Prediction of the number of vehicles}

In this study, the number of vehicles per capita, according to the countries given in Table 1, was used to estimate the maximum vehicle amount. Turkey, Venezuela, Austria, Spain, and France have a similar terrestrial surface area [9]. These countries' vehicle amount per capita rates is $0.145,0.504,0.73$, and 0.478 , respectively. Also, European Countries' average vehicle amount per capita is 0.543 . Capita per $\mathrm{km} 2$ and vehicle amount per capita for some other countries was given in Table 1. When these values are examined, it is estimated that the vehicle amount per capita value will reach a maximum value of 0.5 in our country. Also, it is estimated to reach 110 million worth of Turkey's population in the coming decades. According to this information, the maximum vehicle number (Sm) was accepted as 55 million in 2050.

Table 1. The number of vehicles per capita and the number of people per km2 in 2019 for some countries

[9].

\begin{tabular}{ccc}
\hline Country & Person per $\mathbf{~ k m}^{\mathbf{2}}$ & Vehicle per capita \\
\hline Azerbaijan & 108.4 & 0.101 \\
Turkey & 121.6 & 0.144 \\
Moldova & 123.1 & 0.156 \\
Hungary & 107.0 & 0.345 \\
Slovakia & 113.5 & 0.364 \\
Poland & 123.7 & 0.537 \\
France & 118.9 & 0.578 \\
Spain & 93.7 & 0.593 \\
Australia & 108.7 & 0.717 \\
\hline
\end{tabular}

Table 2. The actual number of vehicles and model results between the years 2007-2018 for Turkey [2].

\begin{tabular}{ccc}
\hline Year & $\begin{array}{c}\text { Actual Number of } \\
\text { Vehicles (million) }\end{array}$ & $\begin{array}{c}\text { Estimates Number of } \\
\text { Vehicles (million) }\end{array}$ \\
\hline 2007 & 13.022 & 13.028 \\
2008 & 13.765 & 13.792 \\
2009 & 14.316 & 14.586 \\
2010 & 15.095 & 15.408 \\
2011 & 16.089 & 16.258 \\
2012 & 17.033 & 17.135 \\
2013 & 17.939 & 18.036 \\
2014 & 18.828 & 18.962 \\
2015 & 19.994 & 19.909 \\
2016 & 21.090 & 20.877 \\
2017 & 22.218 & 21.862 \\
2018 & 22.865 & 22.862 \\
\hline
\end{tabular}

Figure 2 was created using statistical data and estimated data for the number of vehicles. The correlation coefficient of statistical data and forecast data was calculated as 0.9989. This shows that the statistical and forecast data are highly consistent. 
When Figure 2 is analyzed, it is seen that the increase in the number of vehicles continued until 2030 and reached about 35 million values. From 2030 to 2050, it is seen that the number of vehicles has shown a slow increase and reached 49 million values by 2050 .

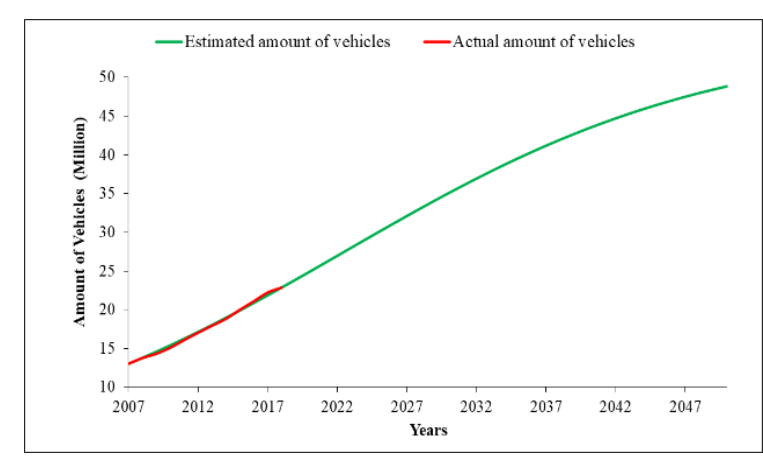

Figure 2. The actual and estimated number of vehicles from the years 2007-2050 for Turkey.

\subsection{Prediction of fuel consumption}

Fuel sales data was used to estimate the amount of fuel consumed annually. Average fuel consumption values give different results for different class vehicles. Therefore, in this study, average fuel consumption was evaluated in three groups as passenger cars, light commercial vehicles, and heavy vehicles. Vehicles in Turkey between 2007-2018 were taken into account for obtaining average fuel consumption data. The average city driving fuel consumption and urban driving fuel consumption data for these vehicles are averaged. Passenger cars were examined in three groups as gasoline, LPG, and diesel. Vehicles in the other two groups were evaluated as diesel. Fuel consumption for passenger cars is assumed as $8.3 \mathrm{lt} / 100 \mathrm{~km}$ in gasoline, $6.8 \mathrm{lt} / 100 \mathrm{~km}$ in diesel, and $9.4 \mathrm{lt} / 100$ $\mathrm{km}$ in LPG, $9.8 \mathrm{lt} / 100 \mathrm{~km}$ for light commercial diesel vehicles. These fuel consumption rates are derived by taking into account the average fuel consumption of the best selling cars in Turkey. The average fuel consumption for heavy-duty diesel engine powered vehicles and buses is also assumed to be $30 \mathrm{lt} / 100 \mathrm{~km}$ considering the full and empty vehicle weights. Fuel consumption estimates can be done for the coming decades using fuel consumption of vehicles and vehicle count data. Therefore, Eq. (5) was used to estimate the total fuel consumption [8]:

$T_{t}=10^{-5} \cdot t_{t} \cdot X \cdot S_{t}$

Where $\mathrm{T}_{\mathrm{t}}\left(\mathrm{m}^{3}\right)$ is defined as total fuel consumption in one year, $t_{t}(\mathrm{lt} / 100 \mathrm{~km})$ is average fuel consumption per $100 \mathrm{~km}$ for vehicles, $\mathrm{X}(\mathrm{km})$ is the average distance traveled for a vehicle, $S_{t}$ is the number of vehicles in a year.

In this study, two different scenarios were created while making fuel consumption estimates. For scenario A (normal), it is assumed that average fuel consumption decreases by $0.08 \mathrm{lt} / 100 \mathrm{~km}$ each year. Besides, it is assumed that the number of diesel vehicles will increase by $0.3 \%$ every year until 2030, and after that year, it will decrease by $0.6 \%$ each year. Unlike scenario A, for scenario B (optimistic), it is assumed that the number of electric vehicles will increase by $0.3 \%$ each year from 2020. Accordingly, it is estimated that the rate of electric vehicles, which will take place in the market will be $9.6 \%$ in 2050 . In this way, it is aimed to examine the effects of diesel and electric vehicles on fuel consumption and emissions. The results obtained for the two scenarios are shown in Figure 3.

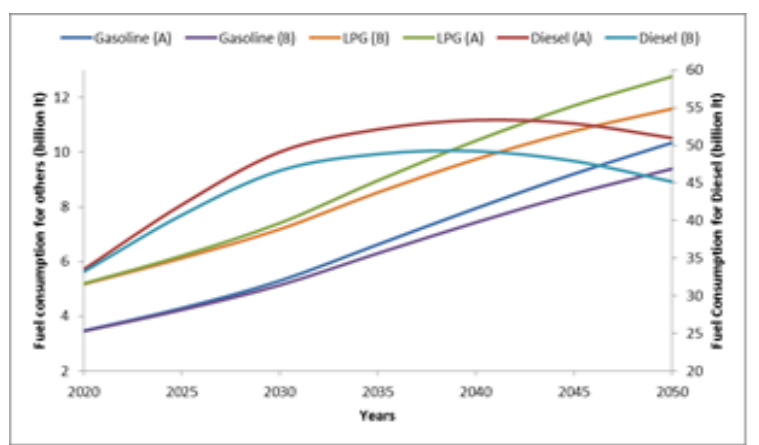

Figure 3. Fuel consumption predictions for the years between 2007-2050 in Turkey.

According to the results obtained, total fuel consumption for scenarios $\mathrm{A}$ and $\mathrm{B}$ are estimated at 74 billion liters and 66 billion liters, respectively, in 2050. It is estimated that diesel fuel consumption will start to decrease as of 2038.

\subsection{Prediction of emissions}

Emission conditions applied in European Union countries started to be implemented with Euro 1 standards in 1992. Euro 4 standards began to be implemented in 2009, and Euro 6 standards began to be applied in 2014. Emission standards are of great importance to reduce air pollution from vehicles. Within this study's scope, exhaust emission amounts were calculated with the number of pollutants per mass fuel burned. 
Table 3. Values of emission factors per vehicle categories for 2017 and 2050.

\begin{tabular}{lccccc}
\hline \multirow{2}{*}{$\begin{array}{l}\text { Pollutants } \\
\text { Year) }\end{array}$} & \multicolumn{5}{c}{ Values of emission factors per vehicle $\left(\mathrm{g}_{\text {pollutant }} / \mathrm{kg}\right.$ fuel $)$} \\
\cline { 2 - 6 } $\mathrm{CO}(2017)$ & 84.7 & 108.26 & 4.44 & 8.142 & 8.07 \\
$\mathrm{CO}(2050)$ & 23.89 & 30.25 & 1.23 & 4.83 & 3.31 \\
$\mathrm{NO}_{x}(2017)$ & 15.2 & 11,62 & 12.51 & 30.25 & 15.49 \\
$\mathrm{NO}_{x}(2050)$ & 2.92 & 2.11 & 1.3 & 1.39 & 1.50 \\
$\mathrm{NMVOC}(2017)$ & 13.64 & 13.46 & 0.99 & 2.152 & 1.61 \\
$\mathrm{NMVOC}(2050)$ & 6.56 & 6.78 & 0.12 & 0.354 & 0.33 \\
$\mathrm{PM}(2017)$ & 0 & 0.03 & 1.38 & 1.22 & 1.78 \\
$\mathrm{PM}_{(2050)}$ & 0 & 0.01 & 0.18 & 0.204 & 0.19 \\
$\mathrm{CO}_{2}(2017)$ & 3024 & 3169 & 3179 & 3174.6 & 3177 \\
$\mathrm{CO}_{2}(2050)$ & 3024 & 3169 & 3179 & 3174.6 & 3177 \\
\hline
\end{tabular}

Cokorilo and Ivkovic estimated these values until 2032 [12]. The emission amounts from 2032 to 2050 have been calculated by considering the changes in Euro Emissions norms by years.

The amount of emission for most vehicle categories in euro norms has stabilized after Euro 4 norms, but NOx emissions have gradually reduced in all categories [13-15]. The amount of pollutants released by the different fuels is given in Table 3 .

Emission prediction until 2050 can be performed by using the emissions values given in Table 3 and the fuel consumption already estimated. The linear decrease was assumed when calculating the total amount of emission, and some values were kept constant. When calculating the amount of emissions, types of vehicles, fuel kinds, percentage of vehicles, and vehicle ages are taken into account. As the calculations are based on fuel consumption, scenario B results are less than scenario A results. Scenario A and scenario B results in estimates for diesel vehicles start to decrease after 2042 and 2041, respectively. As expected, this is because the number of diesel vehicles in the market will decrease. The calculated emission amounts are given in Figure 4 to Figure 9. Scenario A and B were examined in three sections as gasoline, LPG, and diesel vehicles. The change of pollutants from gasoline, diesel, and LPG vehicles for scenario A by years were presented in Figure 4, Figure 5, and Figure 6, respectively. In Figure 4, it can be seen that $\mathrm{CO}$ emissions show a decreasing trend until 2035 thanks to emissions norms. After that, it starts to increase due to increasing gasoline vehicle numbers, and hence fuel consumption for a constant level of $\mathrm{CO} \cdot \mathrm{CO}_{2}$ emissions consistently increase until 2050. When the results for gasoline vehicles are analyzed, $\mathrm{CO}$, $\mathrm{NO}_{\mathrm{x}}, \mathrm{PM}, \mathrm{HC}$ (NMVOC: non-methane volatile organic compounds), and $\mathrm{CO}_{2}$ amounts were estimated as 251.35 kilotons (kt), $8.71 \mathrm{kt}, 0.83$ kt, $59.34 \mathrm{kt}$, and $26331 \mathrm{kt}$, respectively in 2050 . It has been estimated that $\mathrm{NO}_{\mathrm{x}}$ emissions decrease continuously for diesel vehicles. However, $\mathrm{CO}_{2}$ emissions will increase until 2041, and then $\mathrm{CO}_{2}$ emissions will decrease due to decreasing diesel vehicle numbers. The $\mathrm{CO}$, $\mathrm{NO}_{\mathrm{x}}, \mathrm{PM}, \mathrm{HC}$, and $\mathrm{CO}_{2}$ amounts for diesel vehicles were estimated as $52.04 \mathrm{kt}, 54.98 \mathrm{kt}$, $7.62 \mathrm{kt}, 5.08 \mathrm{kt}$, and $134508 \mathrm{kt}$, respectively, in 2050. As a result of the assumption that diesel vehicles will decrease in the coming years within the scope of scenario A, it is concluded that diesel vehicle emissions will decrease as of 2041 compared to previous years. When the LPG vehicle results are analyzed, $\mathrm{CO}, \mathrm{NO}_{\mathrm{x}}, \mathrm{HC}$, and $\mathrm{CO}_{2}$ amounts were estimated as $167.76 \mathrm{kt}$, $9.37 \mathrm{kt}, 46.07 \mathrm{kt}$, and $21235 \mathrm{kt}$, respectively, in 2050. It has been estimated that $\mathrm{CO}_{2}$ emissions increase and $\mathrm{NO}_{\mathrm{x}}$ emissions decrease continuously for LPG vehicles. However, CO and NMVOC values increase because the number of vehicles increases while emission amounts remain constant because of engine technology and combustion limitations.

Another reason for this situation is that vehicles that will be used in the future will be operated not only with the gasoline/electricity system but also with the gasoline/electricity/LPG fuel system. For this reason, it is estimated that the number of LPG vehicles, as well as the $\mathrm{CO}_{2}$ 
emissions, will increase day by day.

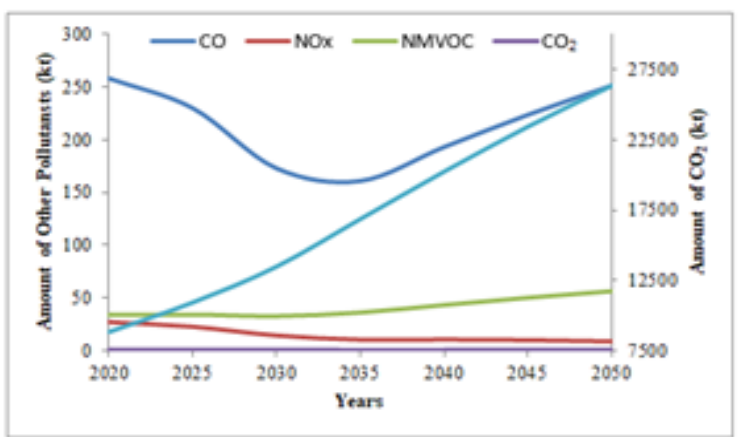

Figure 4. Change of pollutants from gasoline vehicles for scenario A by years

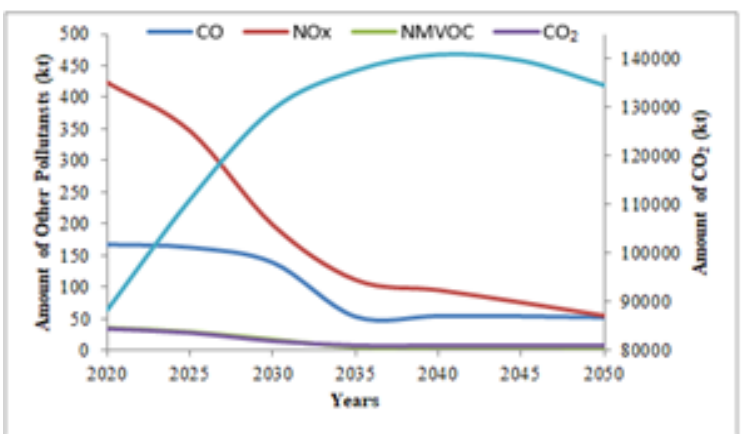

Figure 5. Changes in pollutants from diesel vehicles for scenario A by year

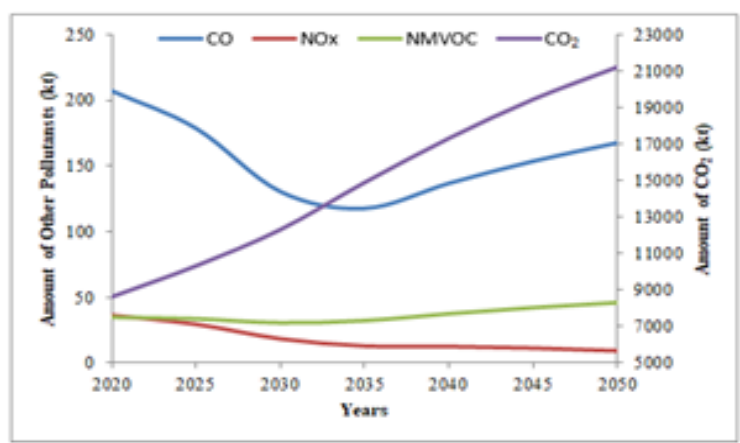

Figure 6. Change of pollutants from LPG vehicles for scenario A by years.

The change of pollutants from gasoline, diesel, and LPG vehicles for scenario B by years were presented in Figure 7, Figure 8, and Figure 9, respectively. When the results for gasoline vehicles are analyzed, CO, NOx, PM, HC, and $\mathrm{CO}_{2}$ amounts were estimated as $228.10 \mathrm{kt}, 7.90$ kt, $0.75 \mathrm{kt}, 51.13 \mathrm{kt}$, and $23896 \mathrm{kt}$, respectively, in 2050. When scenario B is analyzed for gasoline vehicles, it is seen that emission values follow a similar trend to Scenario A. However, considering the emission amounts in 2050 , it is seen that the values for the $\mathrm{B}$ scenario are lower than that of scenario A. The amount of $\mathrm{CO}_{2}$ predicted in scenario B in 2050 is $9.25 \%$ less than anticipated in scenario $\mathrm{A}$. The diesel vehicle results show that $\mathrm{CO}, \mathrm{NO}_{\mathrm{x}}, \mathrm{PM}, \mathrm{HC}$, and $\mathrm{CO}_{2}$ amounts were determined as $46.12 \mathrm{kt}$,
$48.64 \mathrm{kt}, 6.75 \mathrm{kt}, 4.50 \mathrm{kt}$, and $119188 \mathrm{kt}$, respectively, in 2050 . It is seen that the trends for diesel vehicles are similar for the two scenarios. But the amount of $\mathrm{CO}_{2}$ will be estimated at $11.39 \%$ less for scenario B in 2050, compared to scenario $\mathrm{A}$ in 2050. When the results are examined, it can be concluded that electric vehicles have an essential role in reducing $\mathrm{CO}_{2}$ emissions caused by diesel vehicles. When the LPG vehicles' results are analyzed, $\mathrm{CO}, \mathrm{NO}_{\mathrm{x}}, \mathrm{HC}$, and $\mathrm{CO}_{2}$ amounts were estimated as $152.25 \mathrm{kt}, 8.50 \mathrm{kt}, 41.81$, and $19271 \mathrm{kt}$, respectively, in 2050

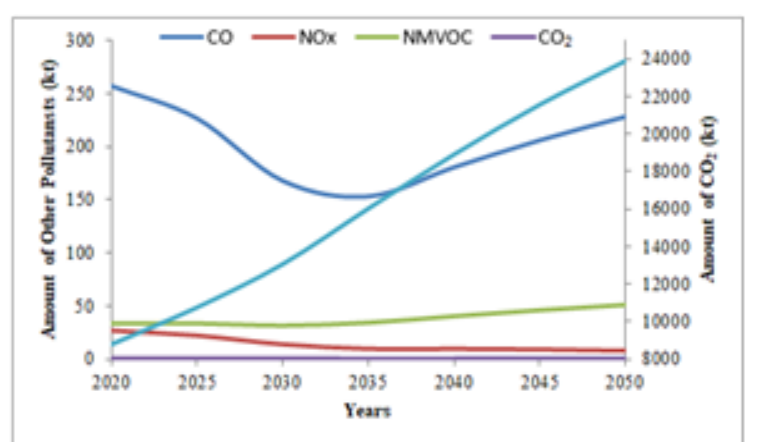

Figure 7. Change of pollutants from gasoline vehicles by year for scenario B

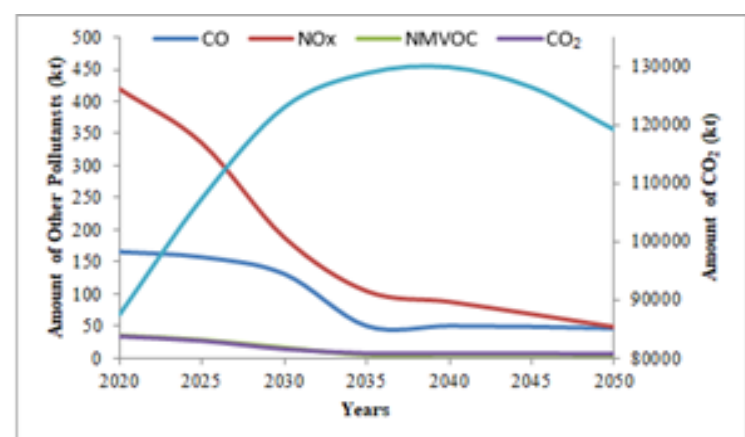

Figure 8 . The number of pollutants from diesel vehicles for scenario B by years

As a result of the assumption that the number of diesel vehicles will decrease in the coming years within the scope of scenario $\mathrm{B}$, it is concluded that diesel vehicle emissions will decrease as of 2040 compared to previous years.

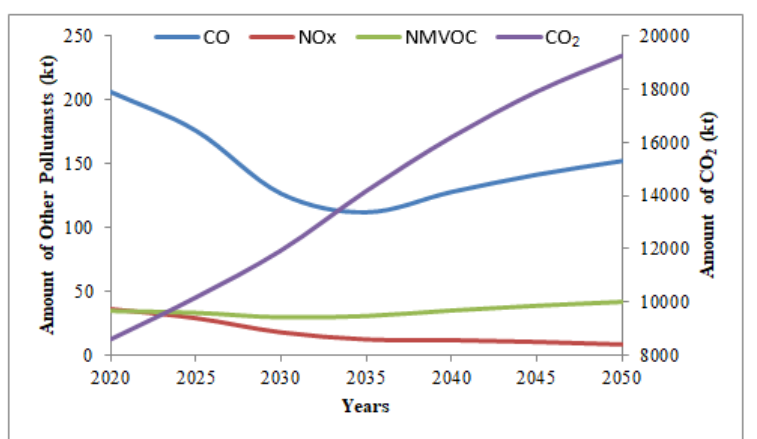

Figure 9. Change of pollutants from LPG vehicles for scenario B by years 
The total amounts of $\mathrm{CO}, \mathrm{HC}, \mathrm{NO}_{\mathrm{x}}, \mathrm{PM}$, and $\mathrm{CO}_{2}$ were predicted as $471.15 \mathrm{kt}, 73.06 \mathrm{kt}$, $107.48 \mathrm{kt}, 8.45 \mathrm{kt}$, and $182075 \mathrm{kt}$, respectively, in scenario A. In scenario B, it was estimated as $426.46 \mathrm{kt}, 65.05 \mathrm{kt}, 97.43 \mathrm{kt}, 7.50 \mathrm{kt}$, and $162356 \mathrm{kt}$, respectively.

\section{Conclusion}

In this study, the number of vehicles between 2007 and 2050 in Turkey was estimated by the Logistic model. Then the amount of pollution generated by vehicles and fuel consumption was also estimated. Based on this study, the following conclusions are drawn:

When taken into consideration the data, it is seen that number of vehicles increases rapidly. It is estimated that the number of vehicles as 22.218 million in 2017 will reach 48.850 million, with an increasing rate of $119 \%$ in 2050. 2018 and 2019 data were used to check the accuracy of the logistic model. The number of vehicles in 2018 and 2019 is 22.865 million and 23.156 million, respectively. The result of the Logistic model for 2018 and 2019 is 22.862 million and 23.876 million, respectively.

As a result of encouraging the use of electric vehicles, their number is increasing day by day. When scenario B is examined, $9.6 \%$ of all vehicles will constitute electric vehicles in Turkey in 2050. The number of electric vehicles is estimated at 1.262 million 2.863 million and 4.689 million for 2030, 2040, and 2050, respectively. In 2050, the number of diesel vehicles, according to scenario $\mathrm{B}$, will be 2.051 million that is less than scenario A.

When A and B scenarios are compared, by 2050, the total $\mathrm{CO}_{2}$ emission difference between the two scenarios is determined as $10.8 \%$. This situation indicates how significant the effect of electric vehicles on emissions. However, the needed electrical energy is should be produced from carbon-free, renewable energy sources.

Alternative fuels are of great importance in preventing air pollution in the future. Also, electric or hybrid vehicles have a reputation for alleviating air pollution. Moreover, alternative energy resources such as fuel cells, solar power, wind power, underground hot water resources must be given much more importance and attention. The increase in electric vehicle numbers alone is not enough to limit emissions. Electricity must also be generated from clean and renewable energy sources.

In future studies, the correlation of different cancer type's incidence with the number of motor vehicles, fuel consumption, and pollutant emissions in Turkey can be revealed. Considering the data presented in this study, the number of cancer patients can be estimated until 2050. Using estimated values, health expenditures to be made for cancer patients in the future can be calculated. The results of these calculations can be used in the planning of incentive programs in the automotive sector.

\section{References}

1. IEA, "Fuel Economy in Major Car Markets. Technology and policy drivers 20052017", Technology report, 2019.

2. https://data.tuik.gov.tr/Kategori/GetKat egori?p=ulastirma-ve-haberlesme-112\&dil=, Date of access: 10 May 2020.

3. https://www.epdk.gov.tr/Detay/Icerik/30-107/yillik-sektor-raporu, Date of access: 21 June 2020.

4. Aktaş, C., Yılmaz V., "Eskişehir'de LPG Kullanan Özel Araç Sürücülerinin Sinıflandırılmasında Lojistik Regresyon Analizi”, İstanbul Kent İçi Ulaşım Sempozyumu, İstanbul, 251-256, 2001.

5. Lewis, D.M., "Forecasting Advective Sea Fog With The Use of Classification And Regression Tree Analyses For Kunsan Air Base", Master's Thesis, Air Force Institute of Technology Graduate School of Engineering and Management (AFIT/ENP), 2004.

6. Ünsal, A., Güler, H., "Türk Bankacılık Sektörünün Lojistik Regresyon ve Diskriminant Analizi ile Incelenmesi”, VII. Ulusal Ekonometri ve İstatistik Sempozyumu, İstanbul University, 2005.

7. Vupa, Ö., Çelikoglu, C., "Model Building in Logistic Regression Models About Lung Cancer Data", Anadolu Ü. Bilim ve Teknoloji Dergisi, cilt: 7, 1, 127-141, 2006.

8. Wu, Y., Zhao, P., Zhang, H., Wang, Y., Mao, G., "Assessment for fuel consumption and exhaust emissions of China's vehicles: Future trends and policy implications", The Scientific World Journal, 2012.

9. Han, H., Yong, G., Joseph S., "Carbon footprint of global passenger cars: Scenarios through 2050", Energy, 101, 121-131, 2016.

10. Solmaz, H., Çelikten, İ., "Estimation of 
Amount of Pollutants Generated by Vehicles in Turkey Until 2030", Gazi University Journal of Science, 25 (2), 495-503, 2012.

11. UN, "World population prospects 2019”, 2019.

12. Cokorilo, O., Ivkovic, I., Kaplanovic, S., "Prediction of Exhaust Emission Costs in Air and Road Transportation", Sustainability, 11, 4688, 2019.

13. Regulation, E. C., "No 595/2009 of the European Parliament and of The Council of 18 June 2009 on type-approval of motor vehicles and engines with respect to emissions from heavy duty vehicles (Euro VI) and on access to vehicle repair and maintenance information and amending Regulation (EC) No 715/2007 and Directive 2007/46/EC and repealing Directives 80/1269, Official Journal of the European Union, 2009.

14. Regulation E.C., "No 715/2007 of the European Parliament and of the Council of 20 June 2007 on type approval of motor vehicles with respect to emissions from light passenger and commercial vehicles (Euro 5 and Euro 6) and on access to vehicle repair and maintenance information", Official Journal of the European Union, L 171/1", 2007.

15. Regulation E.C., "2016/427 of 10 March 2016 amending Regulation (EC) No 692/2008 as regards emissions from light passenger and commercial vehicles (Euro 6)", Official Journal of the European Union, L 82/1, 2016. 